\title{
Influence of the New Media on the Watchdog Role of the Press in Nigeria
}

\author{
Benedict Obiora Agbo, PhD \\ Lecturer, Department of Linguistics and Communication Studies \\ University of Port-Harcourt, Choba, Rivers State, Nigeria \\ Okechukwu Chukwuma \\ Lecturer, Department of Mass Communication \\ Adekunle Ajasin University, Akungba-Akoko, Ondo State, Nigeria
}

doi: 10.19044/esj.2016.v13n2p126 URL:http://dx.doi.org/10.19044/esj.2016.v13n2p126

\begin{abstract}
Section 22 of Nigeria's 1999 constitution indicates that the watchdog role is a constitutional duty of the press to ensure that government is responsible and accountable to the people. However, one major approach deployed by the press to enforce this crucial watchdog role is through investigative journalism. Investigative journalism provides a very potent platform for the press to unravel what is known as "facts behind the facts" particularly in governance. More so, the press is no doubt a beneficiary of the advantages of the new media. The rapidity and ubiquity of the new media is now very visible in journalism practice. The question however is, what is the impact of the new media in the enforcement of the watchdog role of the press? Consequent upon the above question, the researchers assert that the new media have fundamentally aided the execution of the watchdog function of the press. This was premised on the fact that the press now utilise the new media to add depth and context to the coverage of events and issues. The new media now provide wider platforms for not just the press but also the citizens to hold government accountable. With the new media, both the citizens and media professionals now hold government at all levels accountable based on their activities. The new media are now massively used to oppose and criticize government policies and programmes as well as expose government misdeeds such as bribery and corruption with a view to engendering improved government performance.
\end{abstract}

Keywords: Watchdog, New Media,Press, Constitution, Investigation 


\section{Introduction}

In every society, good governance remains a cardinal platform to engender development. Where there is good governance, the wellbeing of the citizens is essentially a priority. On the other hand, bad governance (which is the direct opposite of good governance) is no doubt a fundamental avenue to herald stagnation, retrogression and frustration. The massive advancement in virtually all the developed nations has its root in good governance. To a very significant extent, these developed countries such as Britain, U.S.A., France, Russia, China, etc, have enjoyed the dividends of good governance while the underdeveloped/developing countries (most of which are in Africa) are obvious victims of bad governance.

As earlier indicated, in many underdeveloped/developing nations such as Nigeria, bad governance has consigned the countries into a state of frustration. Citizens cannot properly feed, access good water, acquire good clothes and decent homes. They cannot access quality education, good roads, healthcare etc. We have inadequate learning facilities, poor learning environment and consistent teachers' strike at both the pre and post tertiary education levels. In the health centres, health workers are often on strike for reasons which amongst others entails poor working condition. We equally have the issue of inadequate healthcare equipment and many more. Monies meant to address these situations are often embezzled by corrupt officials. In line with the above submission, Udeze (2005, p.101) asserts that;

The looting of the treasuries of different African countries by her leaders has left most of these countries in a big mess. The money that could have been used to build roads, factories that will absorb unemployed young men and women to make them live decent and honest life, are carried away by the political class... The unemployed ones who are not principled become armed robbers, thugs...

At the heart of bad governance is essentially corruption. Corruption is said to be the biggest and most thriving industry in Nigeria. The menace of corruption has taken very firm root in the country to the extent that it is almost a norm. In Nigeria, rather than arrest and prosecute corrupt officials, these people are greatly celebrated as heroes. Most of them are given chieftaincy titles while some are as well given awards. The security agents are no exemption. The ill of collecting money from bus drivers just to let them go unsearched is still been perpetrated by some corrupt Police Officers 
despite all the warnings. Writing on the menace of corruption in Nigeria, Udeze and Chukwuma (2011, p.305) assert that

Corruption is a very devastating challenge

Nigeria has been battling with for decades, and yet, it has remained a recurring decimal. More worrisome is the fact that even those placed in highly respected political positions end up looting the funds budgeted to better the lives of the people and in the end, nothing is done to prosecute them. Even when they are arrested for prosecution, after the razzmatazz, their cases just die natural deaths because of their powerful influences. Because nothing is done to those who stole, the next group takes corruption to the next level. Today, one can talk of mega corruption in Nigeria.

Our leaders have continued to reap the nation of our collective wealth. The level of corruption amongst our leaders is heart-breaking and very unimaginable. The monumental level of corruption in governance has resulted to governments' inability to bring succour to the poor masses (Udeze and Chukwuma, 2012, p.64).

As a way of holding our leaders accountable and responsible to the people, the watchdog role of the press was introduced. The watchdog function of the press is essentially to hold government accountable. It is a crucial role that empowers the press to checkmate governments' activities with the core aim of engendering good governance. This function of the press has its root in section 22 of Nigeria's 1999 constitution. The section states clearly that, "the press, radio, television and other agencies of the mass media shall at all times be free to uphold the fundamental objectives contained in this chapter and uphold the responsibility and accountability of government to the people”.

The above stated section of Nigeria's constitution indicates that the watchdog role is a constitutional duty of the press to ensure that government is responsible and accountable to the people. The section places a crucial demand on the press to instill accountability and responsibility in governance with a cardinal intention of wading-off corruption which will ultimately herald good governance that will advance the wellbeing of the citizens. Laying credence to the above, Idumange (2013, para. 7) asserts that "The media are expected to monitor "happenings", especially activities of the government, and report same to the entire society. In addition, they are expected to uphold the responsibility and accountability of the government 
to the society”. Writing on the watchdog role of the press, Graber (1993, p.35) averred that;

One role of the media in a democracy is that of watchdog over government. The idea is that the press should dig up facts and warn the public when officials are doing something wrong. Citizens can hold officials accountable for setting things right only if they know about errors and wrongdoing.

A fearless and effective watchdog is critical in fledgling democracies such as Nigeria where existing democratic institutions are weak and pummeled by political pressure. The watchdog role of the press is all the more important because the critical arms of government: the legislature and the judiciary seem to have neglected their oversight functions hence they are powerless as mechanisms of social control. Thus the media are often left as the only check against the abuse of power, criticize corruption with a view to entrenching transparency, accountability and strengthen democratic fledging institutions (Idumange, 2013, para. 11).

The watchdog conception, according to which, the media is supposed to serve as a controller of government, is one among the oldest main beliefs in journalism. The term 'fourth estate', the press' role in being a 'watchdog' that will control the government was reputedly coined by Edmund Burke, in late-eighteenth century in England to refer to the political power possessed by the press of that time, on a same level with the other three 'estates' of power in the British realm: Lords, Church and Commons (McQuail, 2005, p.169).

From the above assertion by McQuail, the press is referred to as the fourth estate of the realm while the executive, legislature and the judiciary are the first, second and third estates respectively. As stated earlier, the legislature and the judiciary seem to have neglected their oversight functions thereby leaving the fourth estate (press) with no choice than to solely perform the watchdog role of exposing government misdeeds. In this wise, Akinfeleye (2003, p.11) notes that "the press is to watch-dog, check-on-to uncover and never to cover up corruption and/or wrong doings by the other three estates. They are also to monitor governance and make the other three estates accountable to people at all times." Writing on the importance of the watchdog function, Mojares (2006, p.8) cited in Kane (2013, p.14) avers that;

Watchdog journalism can lead to the successful resignation of power holders. A well-known example is the 
reporting of Bob Woodward and Carl Bernstein on the Watergate scandal for

The Washington Post and the subsequent resignation of U.S. president Richard Nixon in 1974. Another more recent example took place in the Philippines, where President Joseph Estrada was arrested and resigned in 2001. The daily newspaper, Pinoy Times, covered the case of Estrada till the ouster of Estrada.

Amongst the many cases in Nigeria, one case worthy of mention is the case of Hon. Patricia O. Etteh's scandal. She was accused of financial mismanagement and was pressured to resign as the Speaker of the Federal House of Representatives. Despite all her efforts and that of her sponsors to remain in office, she was left with no other choice than to turn-in her resignation which saw the emergence of Hon. Oladimiji Bankole as the new Speaker of the House during that dispensation. In this line, the press have continued to do the much they can to fulfill the watchdog function.

Currently, the watchdog role of the press has gone beyond just investigating government and its agencies, to also include private individuals that have such need to be investigated. As Ibrahim (2007, p.1) cited in Abubakar (2012, p.6) noted;

In the beginning, the idea of the press as the 'fourth estate' was considered as an independent check on the activities of the state, particularly government. On the other hand, the development of the watchdog role goes further than the borders of government investigation to take account of many other institutions of societal power, including powerful individuals, who may have no official relationship with public office.

One major approach deployed by the press to enforce this crucial watchdog role is through investigative journalism. Investigative journalism provides a very potent platform for the press to unravel what is known as 
"facts behind the facts" particularly in governance. Through investigative journalism, the press conducts intense investigations to unearth hidden facts.

The emergence of the new media has redefined the patterns of communication globally. In recognition of the importance of the new media, the press have massively began to utilize them (new media) in the practice of journalism. Both the broadcast and the print media journalists now use the new media to discharge their duty of information gathering and dissemination. In fact, journalism practice has taken a new dimension of been more interactive, timely, and interesting.

The way in which news is conceptualized, gathered, produced, disseminated or consumed is changing in the context of new communication technologies. Earlier research on the impact of new media technologies on journalism practice has tended to focus more on how these technologies have reconfigured news production, dissemination and consumption practices. New media technologies, such as the mobile phone enable journalists to gather news from every nook and cranny of the globe, and send text messages to their newsrooms with relative ease. Others demonstrate how the internet provides media personnel with unlimited access to information on any subject, and how email newsgroups allow journalists to “... tap into the collective brain, wit and wisdom of thousands of knowledgeable journalists and non-journalists” (Berger, 1997, p.124)

The question however is, what is the impact of the new media in the discharging the watchdog role of the press in Nigeria? The above question formed the basis for this paper.

\section{An Overview of the New Media}

The new media are those methods and social practices of communication, representation and expression that have developed using digital, multimedia, networked computer and the ways that this machine is held transformed work in other media, like books, movies, newspapers, magazines, radio, television, telephone etc (Diri, 2009, p.177).

The new media can also be defined as the desperate sets of communication technologies that share certain features, apart from being new, made possible by digitalization and being widely available for personal use as communication devices (Mcquail, 2010, p.136).

The various internet-based applications, from social networks to usergenerated content and micro-blogging, have empowered nearly every user of the new media to be a potential broadcaster, with the ability to rapidly create, modify, and share digital contents and knowledge with millions of other users both locally and globally. This trend encourages new and emerging patterns of communication, demolishes artificial borders, while creating a participatory and new forms of other creative expression. This way, more 
people get to express themselves and participate in public debates more than before. (Adelabu, 2011).

With the various platforms the new media offer, it is possible for almost any citizen to communicate to a large and diversified audience either through blogs, social networking sites, internet groups and chat-rooms. Now, it is much easier for citizens around the world to challenge authorities on issues, expose corruption, and express their opinions via new media. Images that would have been censored by media houses based on their sensitive nature, get frequently circulated online. Online, people make comments and write without restraints. The opening of these new frontiers has provided opportunity for the media to enhance the operations (Adelabu, 2011).

New media channels have formed a global interactive web community where connected people can easily share ideas, messages and update themselves on any unfolding happening in the world. Through this, people easily get informed more than any other source. Perhaps, Essoungou (2010, para. 5) had this in mind by averring that the "new media could help raise awareness." The availability of these new communication channels is yet another edge both the broadcast and the print media individually, it is certain that the 'family' of the new media is in the electronic genre of journalism (Ahmed, 2013, p.109).

\section{A Brief Overview of the Watchdog Role of the Press}

The watchdog function of the press is essentially to hold government accountable. It is a crucial role that empowers the press to checkmate governments' activities with the core aim of engendering good governance.

The watchdog role is a constitutional duty of the press to ensure that government is responsible and accountable to the people. This watchdog function places a crucial demand on the press to instill accountability and responsibility in governance with a cardinal intention of wading-off corruption which will ultimately herald good governance that will advance the wellbeing of the citizens. Laying credence to the above, Idumange (2013, para. 7) asserts that "The media are expected to monitor "happenings", especially activities of the government, and report same to the entire society. In addition, they are expected to uphold the responsibility and accountability of the government to the society". Writing on the watchdog role of the press, Graber (1993, p.35) averred that;

One role of the media in a democracy is that of watchdog over government. The idea is that the press should dig up facts and warn the public when officials are doing something wrong. Citizens can hold officials accountable 
for setting things right only if they

know about errors and wrongdoing.

The watchdog conception, according to which, the media is supposed to serve as a controller of government, is one among the oldest main beliefs in journalism. The term 'fourth estate', the press' role in being a 'watchdog' that will control the government was reputedly coined by Edmund Burke, in late-eighteenth century in England to refer to the political power possessed by the press of that time, on a same level with the other three 'estates' of power in the British realm: Lords, Church and Commons (McQuail, 2005, p.169).

\section{Empirical Review of Journalists' Utilisation of New Media in Discharging the Watchdog Role of the Press in Nigeria}

As stated earlier, journalists (in recognition of the importance of the new media platforms) are massively using them in the practice of journalism. In fact, contemporary journalism has left journalists with no option than to employ the new media in information gathering and dissemination. Virtually all journalists and media houses now deploy the new media to aid their business of journalism. A study entitled "An Evaluation of the use of the New Media in Journalism Practice amongst Journalists in South-East Nigeria” was conducted by Woke in 2013. Selected journalists in Anambra, Abia, Imo, Ebonyi and Enugu States were used as respondents. Using survey research method and observation, findings revealed that the journalists and their various media houses massively used the new media in the practice of journalism. In line with this, Ahmed conducted a study on "The Use of the New Media in the Practice of Journalism in Nigeria”. In the used, Ahmed used selected broadcast and print media journalists in the six geopolitical zones as respondents. The findings of the study showed amongst others that there is a significant use of the new media in journalism practice in Nigeria. Also, the studies of Adeyemi, 2012, Kalu, 2013, Kang, 2012 and Hassan 2012, all gave credence to the fact that the conventional media are significantly using the new media to enrich their practice of journalism.

As observed in the findings of the studies reviewed above, the new media are massively been used by Nigerian journalists to discharge their duty of information gathering and sharing. Individual journalists and their various media affiliations have embraced the new media in the practice of journalism in Nigeria. But the question still remains, what is the impact of the new media in the performance of the watchdog role of the press in Nigeria? Indiago (2013, p.11) notes that;

In Nigeria, the new media have significantly aided journalism practice in general and the watchdog role in 
particular. The emergence has widened the space for information gathering and dissemination. It has served as an avenue for journalists to access relevant information that has aided their investigations on governments at all levels, their agencies and other individuals worthy of investigation.

The new media have indeed redefined investigative journalism in Nigeria. It has enhanced the enforcement of the watchdog role of the press. Today, Nigerian journalists beckon on the new media for critical information they may not have ordinarily access elsewhere. This is because someone somewhere who has access to such information made it available via the new media (Damola, 2012, p.16).

A study entitled "New Media Influence on Watchdog Journalism in Nigeria” was conducted in 2013 by Kazeem”. Kazeem used selected journalists in the country as his respondents. Using the survey research method and in-depth interview, Kazeem found that the new media have enhanced the watchdog role of the press based on the premise that journalists get clues, and other expedient information needed to aided investigation. In a related study entitled "The Role of the New Media in the Performance of the Watchdog Function of the Press" which was conducted in 2012 by Morris and Angaghe, findings revealed that the new media have significantly aided the watchdog role of the press in Nigeria.

Furthermore, Bakare in 2013 did a study entitled "The New Media and the Watchdog Role of the Press in Nigeria". Indepth-interview and observation were used to execute the study. Findings from the study showed that the use of the new media have to a large extent aided the discharge of the watchdog function of the press in Nigeria.

Findings from the studies reviewed above among others point to one core issue which is that the new media have enhanced the performance of the watchdog role of the press in Nigeria. However, it is expedient to explore the various ways the new media have aided the performance of the watchdog role. Therefore, the next stage of this discussion is devoted to addressing this concern.

\section{The Impact of the New Media on the Watchdog Role of the Press in Nigeria}

The next question that needs clarification in this discourse is how have the various new media platforms enhanced the watchdog role of the press? Put differently, in what way(s) have the new media aided the watchdog function of the press in Nigeria? 
The first response to the above question is through citizen journalism. Citizen journalism which is made possible by the new media is a cardinal practice that has essentially aided the watchdog function. The new media now provide wider platforms for not just the press but also the citizens to hold government accountable. With the new media, both the citizens and media professionals now hold governments at all levels accountable based on their activities. The new media are now massively used to oppose and criticize government policies and programmes as well as expose government misdeeds such as bribery and corruption with a view to engendering improved government performance. As Clark (2013, p.8) notes;

The emergence of the new media has provided the opportunity for the Nigerian citizens to join the expedient duty of holding government accountable. With the aid of Facebook, Twitter, Youtube, etc, both journalists and the citizens now join forces to ensure the accountability and responsibility of government.

With the various platforms the new media offer, it is possible for almost any citizen to communicate to a large and diversified audience either through blogs, social networking sites, internet groups and chat-rooms. Now, it is much easier for citizens around the world to challenge authorities on issues, expose corruption, and express their opinions via new media. Images that would have been censored by media houses based on their sensitive nature, get frequently circulated online. Online, people make comments and write without restraints. The opening of these new frontiers has provided opportunity for the media to enhance the operations (Adelabu, 2011).

The second point here is that the new media have significantly added to the variety of sources for investigation. With the new media, journalists now have more sources to access very relevant information that will aid their watchdog function. Today, much sensitive information regarding the misdeeds of government and its agencies are uploaded by citizens with a core intention of exposing the ills in governance. Also, the variety of sources helps in the verification/confirmation of information. The avalanche of sources which the new media is a major contributor provides the journalist with better opportunity to properly cross-check facts in the performance of the watchdog role. To ensure the information at their disposal is accurate, the various new media sources are maximally utilized to verify the stories before they are published. Accordingly, Ani (2014) found in his study that the new media have expanded the scope of sources available for Nigerian journalists 
to access and transmit information that will aid the discharge of their watchdog function.

Furthermore, the new media help to bring government activities much closer to the Nigerian citizens thereby making it possible for the citizens to fully participate in the performance of the watchdog function. Various government activities are streamed on Facebook, Twitter, YouTube, Short Message Service, etc, and gadgets such as ipod, mobile phones, ipad, etc are used used in this regard. The streaming by government is done with the priority intention of letting the citizens know about these activities. This provides a good platform for the citizens to join professional journalists in performing the watchdog role. When one is familiar with the activities of government, it places one in a good position to properly criticize those activities with the ultimate aim of engendering good governance. Giving credence to this, Njoku (2014) found in his qualitative study that the new media platforms have provided opportunity for non-journalists to join professional journalists in performing the watchdog function by criticizing government activities with the aim of ensuring good governance in Nigeria.

It is also in place to aver that the new media have made the watchdog role of the press easier and faster in Nigeria. In this regard, what Joseph Dominick called "Back Pack Journalism" comes to mind. Here, the journalist does everything by himself. For instance, the journalist deploys the smart phone to conduct his investigations which amongst others include taking pictures of stolen money, property, fake contracts and other fraudulent activities of government and its agencies. Also, the smartphone is used to record interviews with sources and other information that will enhance the performance of the watchdog function.

\section{Challenges of Journalists' Utilisation of the New Media in Performing the Watchdog Role of the Press}

Despite the fact that the new media have positively impacted on the performance of the watchdog role, some challenges abound. These challenges impede the press' maximal use of the new media in the enforcement of the watchdog function.

The insufficient or unavailability of new media facilities such as the smartphones, laptops, Ipods etc is a serious impediment to using the new media in the performance of the watchdog function of the press. Even situations where these facilities are said to be available, they are not adequate. To this end, the need to make the new media facilities not just available but sufficiently available becomes very pertinent. This is owing to the fact that contemporary journalism practice demands the use of the new media. It is unarguably a fact that any media establishment or journalist who wants to remain relevant in the current trend of journalism practice must 
embrace the new media and deploy them to aid their practice of journalism. Wilson, (2013, p.7) revealed in his study that some Nigerian journalists are yet to have access to new media facilities for contemporary journalism practice.

Lack/poor Internet connectivity is as well a challenge in using the new media to discharge the watchdog function of the press in Nigeria and other developing nations. There are many locations in these nations where internet connectivity is unavailable. Even at locations where the internet can be accessed, fluctuating network is sometimes unavoidable. This makes it impossible for journalists to fully harness the internet to access and transmit relevant information that will be beneficial to the journalists' watchdog function. Smith (2014, p.11) found that some parts of Nigeria, especially the rural areas experience lack or poor internet connectivity thereby hindering the journalists from adequately using the new media gadgets to discharge their functions including the watchdog role.

Also very fundamental amongst the challenges is the challenge of skill. For any journalist to effectively use the new media in performing the watchdog function, the need to possess adequate skill to operate the new media is no doubt very expedient. This is premised on the fact that the new media are very sophisticated technologies that require adequate knowledge for efficient utilization. Some Nigerian journalists lack the requisite skills to efficiently use the new media gadgets to aid their practice of journalism. This is as well visible in many African countries. In Nigeria, we refer to this set of journalists as "analogue journalists". This implies that these journalists do not possess the needed skills to operate digital gadgets. Nwafor, (2013) finding points to the direction that there are some Nigerian journalists who do not have the requisite skill to use new media gadgets. In this regard, journalists must continue to undergo training and retraining to acquire the requisite skill that will enable them properly use the new media to fulfill the obligation of the watchdog.

The issue of credibility/public suspicion is as well another impediment. In most developing climes like Nigeria, the culture of casting doubts on what is seen and read online is still visible. Some people have not fully come to terms with the fact that online sources have come to constitute very important avenue to access relevant information regarding various issues. They do not trust the information they access online. The tendency to only believe what they read and listen/watch on the conventional media still has its root in the citizens. This therefore put to suspicion information generated online through the new media in the discharge of the watchdog function. Similarly Hassan (2013) found that "suspicion among Nigeria audience regarding messages on new media/online platforms constitute a 
major challenge to its usage by journalists”. But enlightenment continues to be the core remedy to this misconception.

Furthermore, the attitude of journalists regarding the use of the new media in performing the watchdog function is also one of the core challenges. This is because some journalists have become too used to their old ways of doing things to the extent that they are now very conservative to embracing the contemporary trend of journalism practice. Because of their conservative nature, some journalists have refused to develop favourable attitude towards the use of the new media in discharging the watchdog role. They should as well be told the implication of continuing with the old pattern of journalism practice. The findings of Mohammed (2014) and Adebola (2013) gave support to this assertion. Sequel to the above, this set of journalists must be made to fully understand the need to accept and utilize the new media in the practice of journalism.

\section{Conclusion}

Based on the discussion above, the researchers conclude that the new media have fundamentally aided the execution of the watchdog function of the press. This was premised on the fact that the press now deploy the new media to add depth and context to the coverage of events and issues. The new media now provide wider platforms for not just the press but also the citizens to hold government accountable. With the new media, both the citizens and media professionals now hold governments at all levels accountable based on their activities. The new media are now massively used to oppose and criticize government policies and programmes as well as expose government misdeeds such as bribery and corruption with a view to engendering improved government performance.

\section{References:}

1. Abubakar, E.L. (2012). An exploratory study of the watchdog role of the press. Journal of Communication Research. 2(1). 1-15.

2. Adebola, S.E. (2013). An analysis of Nigerian journalists' attitude towards new media usage in journalism practice. Journal of Mass Communication. 5(1). 1-11.

3. Adelabu, T. (2011). Waiting for a legislative framework in Nigeria. Punch Newspaper, February 25, 2011.

4. Ahmed, I.A. (2013). An evaluation of the knowledge and use of the new media in selected African nations. International Journal of Information and Communication Technology. 4(1). 107-115.

5. Akinfeleye R. A, (2003). Fourth estate of the realm of fourth estate of the wreck: Imperative of the social responsibility of the press. Lagos: University of Lagos Press. 
6. Ani, A.V. (2014). The new media and the expanding sources of information. Journal of Communication and Innovatiion. 3(1). 91-38.

7. Bakare, S.V. ( 2013). The new media and the watchdog role of the press in Nigeria. Journal of Contemporary Journalism Studies. 3(1). 57-69.

8. Clark, R. L. (2013). New Media and Citizen Journalism. A critical discourse. Journal of Media and Communication Studies. 2(2). 113.

9. Damola, D.I. (2012). The new media in contemporary journalism practice. Journalism of Communication and Governance. 1(1). 98-113.

10. Diri, C. T. (2009). Old media, new media: An exploration in relevance, convergence and divergence. International Journal of Communication. N0. 10, pp. 174-187

11. Graber, D. (1993) Mass Media and American Politics, (4 ${ }^{\text {th }}$ ed.). Washington, D.C.: $\quad$ Congressional Quarterly Press.

12. Hanh, M. H. (2012). A discourse on the new media and citizen journalism. Journal of Media Studies. 4(2). 1-12.

13. Hassan (2013). Public perception of the use of new media in journalism practice. Journal of New Media and Mass Communication. 3(2). 1-17.

14. Kane, O.W. (2013). An analysis of watchdog journalism. Journal of Journalism Studies. 3(1). 1-17.

15. Kazeem, I. C. (2013). New media influence on watchdog journalism in Nigeria. Journal of New Media and Politics. 1(1). 46-58.

16. McQuail, D. (2005). Mass communication theory. London: SAGE Publication.

17. Mcquail, D. (2010). Mcquail's mass communication theory. $\left(6^{\text {th }}\right.$ Edition). London: SAGE Publications.

18. Mohammed, I.A. (2014). A study of Nigerian journalists' disposition towards using the newmedia for journalism practice. Journal of Media Studies. 3(1). 15-29.

19. Morris, S. F. and Angaghe, M. H. (2012). The role of the New Media in the performance of the watchdog function of the press in Nigeria. Journal of Journalism and Good Governance. $\quad 7(3)$. 7186.

20. Njoku, D.H. (2014). A qualitative analysis of citizens and professional journalists' discharge of the watchdog role. Journal of Mass Communication. 4(2). 1-19. 
21. Nwafor, E.I. (2013). An evaluation of the knowledge and use of the new media in journalism practice among Nigerian journalists. Journal of Communication Studies. 2(1). 12-2.

22. Smith, G.L. (2014). The effect of poor/lack of internet connectivity in the practice of contemporary journalism. Journal of Science and Technology. 7(1). 1-16.

23. The 1999 Constitution of the Federal Republic of Nigeria.

24. Udeze, S.E. (2005). After the whirlwind: A discourse on international communication. Enugu: Rhyce Kerex Publishers.

25. Udeze, S.E. and Chukwuma, O. (2011). Political apathy in postcolonial Nigeria: The mass media imperative. In ESUT Journal of Management Sciences. 6 (2). 299-314.

26. Udeze, S.E. and Chukwuma, O. (2012). The rebranding Nigeria project: Myths, realities and the way forward. In Nigerian Institute of Public Relations (NIPR) Journal. 8(2). 59-66.

27. Woke, K. B. (2013). An Evaluation of the use of the New Media in Journalism Practice amongst Journalists in South-East Nigeria. Journal of Communication and Development Research. 3(1). 37-43.

28. Wilson, I. (2013). Awareness and access to new media gadgets among Nigerian journalists. Journal of Linguistics and Communication Studies. 2(1). 1-13. 